\title{
Size and age at first copulation and spawning of the apple snail, Pomacea canaliculata (Gastropoda: Ampullariidae)
}

\author{
Gerardo F. Estoy, Jr., ${ }^{*}$ Yoichi Yusa, ${ }^{1}$ Takashi Wada, ${ }^{1}$ Hironori Sakurai and Koji Tsuchida \\ Laboratory of Entomology, Faculty of Agriculture, Gifu University, Gifu 501-1193, Japan \\ ${ }^{1}$ National Agricultural Research Center for Kyushu Okinawa Region, Nishigoshi, Kumamoto 861-1192, Japan \\ (Received 20 August 2001; Accepted 7 December 2001)
}

\begin{abstract}
The size and age at first copulation and spawning of the apple snail, Pomacea canaliculata, were determined at three food levels under laboratory conditions $\left(14 \mathrm{~L}: 10 \mathrm{D} ; 25^{\circ} \mathrm{C}\right)$. Males fed at a low food level started copulation at smaller sizes than males at higher food levels. However, age at first copulation was similar among snails at all food levels. The food level appeared to affect the penis sheath length at maturity, although the difference did not reach a statistically significant level. Females fed at the low food level delayed both first copulation and spawning longer than those at higher food levels. Consequently, their sizes at first copulation and spawning were smaller. The albumen gland of poorly fed snails was smaller at first copulation but comparable at maturity. The adaptive significance of these patterns in sexual maturity and their possible implications for the integrated management of this snail are discussed.
\end{abstract}

Key words: Pomacea canaliculata, size, age, maturity, food

\section{INTRODUCTION}

Timing of maturity and reproductive effort are the two most important life history components affecting fitness of an organism in a given environment (Roff, 1992). The timing of maturity, in terms of size and age, is affected by many environmental factors. Stearns and Koella (1986) reviewed and predicted the evolution of phenotypic plasticity in life history traits of organisms. They pointed out that food availability affects size and age of individuals at maturity, and responses to food availability can be different even in males and females of the same species.

In the apple snail, Pomacea canaliculata, density dependent growth and reproduction occur in the paddy, presumably owing to different food availabilities (Tanaka et al., 1999). Understanding the effects of food availability on the reproductive traits will give insights into individual fitness, hence, population dynamics of this pest snail. Thus, practical methods of snail management can be determined and implemented. Unfortunately, little is known on how direct manipulation of food availability may affect the reproduction of the apple snail. This study examines the influence of three food levels on snail size and age at first copu- lation and spawning under laboratory conditions.

\section{MATERIALS AND METHODS}

The apple snails were collected from rice fields in Shichijo, Kumamoto, Southwest Japan in September and October 2000. The collected immature $(8.8-9.5 \mathrm{~mm})$ and mature snails $(27.5-30.0 \mathrm{~mm}$; cf. Kaneshima et al., 1986) were brought to the laboratory. The mature snails were sexed based on shell morphology (Cazzaniga, 1990) and were stored dry at $15^{\circ} \mathrm{C}$. Immature snails were reared in three $60 \mathrm{l}$ aquaria $(60 \mathrm{~cm} \times 30 \mathrm{~cm} \times 40 \mathrm{~cm})$ and fed cabbage until they reached the desired shell height (15.0 $18.0 \mathrm{~mm}$ ). Aquaria were artificially illuminated with white fluorescent lights (ca. 2,000 lx at water surface). Photo regime was 14L:10D and temperature was $25^{\circ} \mathrm{C}$. Once the immature snails attained the desired shell height, the stored dry mature snails were activated by putting them in another aquarium and feeding them cabbage. The immature snails were sexed before the start of the experiment by slightly opening the operculum to check the presence or absence of the penis sheath. Mature snails paired with the opposite sex were individually transferred into a plastic pot $(2.3 l)$, covered with plastic net ( $1.5 \mathrm{~mm}$ eyehole) and overlaid with

\footnotetext{
* To whom correspondence should be addressed.
} 
rubber band to prevent their escape. Vinyl plastic bag $(260 \mathrm{~mm} \times 380 \mathrm{~mm})$ was placed inside the plastic pot before addition of water to facilitate spawn collection. The quantity of water in the plastic pot was approximately $1.7 \mathrm{l}$. A small amount of powdered oyster shell was added after the water was changed as a calcium supply.

Sixty test female snails and 40 test male snails with their partners were assigned to each of the three treatments: high food level (food was available daily), medium food level (fed $4 \mathrm{~d} /$ week) and low food level (fed $2 \mathrm{~d} /$ week). Cabbage was used as the main food for the snails because it lasts longer than lettuce, which is usually used for snail rearing, when soaked in water (Estebenet and Cazzaniga, 1992). Cut fresh cabbage leaves were provided in excess to the snails. However, their availability depended on what food level treatment the snails were assigned. At the high food level, cabbage was renewed every time the water was changed (Monday and Friday) and sometimes renewed on Thursday. Cabbage was given to the snails in the medium and low food levels after the water was changed on Monday. It was removed at water change on Friday in the medium food level and on Wednesday at the low food level. Thus, we established three food levels. In all food levels, water was changed twice a week (Monday and Friday) to avoid foul odor and low oxygen levels (Estebenet and Cazzaniga, 1992). In P. bridgesii, artificial diets (20-30\% protein) resulted in better growth than snails fed with dehydrated lettuce (Mendoza et al., 1999). Hence, carp pellet $(32 \%$ protein content; Hikari, Kyorin Co., Ltd., Himeji, Japan) was given at 1 pellet $(0.2 \mathrm{~g}) /$ week as supplementary food for the snails. The carp pellet was given a day before the water was changed to ascertain that no residues were left on the plastic pot.

Since the snails were field collected and their initial conditions before collection were unknown, the pairs were randomized in terms of body size among the food levels. Consequently, no significant differences were observed among test female snails in initial shell height ( $p>0.9$; ANOVA) and weight $(p>0.4)$ or among test male snails in initial shell height $(p>0.9)$ and weight $(p>0.8)$. Moreover, no significant differences were recorded among partners of the test female snails in initial shell height $(p>0.8)$ and weight $(p>0.2)$ or among partners of the test male snails in initial shell height $(p>0.5)$ and weight $(p>0.5)$.

Shell height of the test snails was measured with calipers to the nearest $0.1 \mathrm{~mm}$ and weight (blotted dry) was measured with a sensitive balance to the nearest $0.01 \mathrm{~g}$ at almost biweekly intervals from the start until the end of the experiment (182 d). Copulation and spawning were checked twice daily (8:30-9:30 am and 8:30-9:30 pm). Snails were considered to be copulating when the penis sheath of the male was inserted into the mantle cavity above the right nuchal lobe of the female (Albrecht et al., 1996). At first copulation or spawning, the snails were weighed and their shell heights determined. Eight to eleven snails were randomly chosen both at first copulation and spawning from each food level. They were killed by freezing and dissected to measure penis sheath length of the test male snails and albumen gland weight of the test female snails. The penis sheath was pressed gently with a pair of forceps from its tip to the sheath basal outer gland (Thiengo, 1987) until its full length was attained and measured with calipers. The albumen gland was blotted dry before it was weighed on a sensitive balance. All the snails were killed by freezing after the experiment and dissected later to verify their sexes. Four and two "female" individuals in the low and medium food levels, respectively, turned out to be males. Thus, they were excluded from the analyses.

Measurements on shell height, weight, albumen gland weight and penis sheath length were subjected to ANOVA, and multiple comparisons of means between food levels were evaluated with the Tukey-Kramer test. The albumen gland weights were further analyzed using the unpaired $t$-test to compare weights at first copulation and first spawning. The proportions of dead or live snails were subjected to $G$-test. Relative age at first copulation (days from start of experiment until the first copulation were observed) was compared based on the total number of snails that copulated in all food levels as almost all snails copulated. However, relative age at first spawning (days from start of experiment until the first spawn) was compared in the first $50 \%$ of spawning females as well as total number of spawning females, because not all snails spawned and the proportions of spawning females were different among food levels. Data on the relative ages at first copulation and spawning were subjected to Kruskal-Wallis test because they were not 


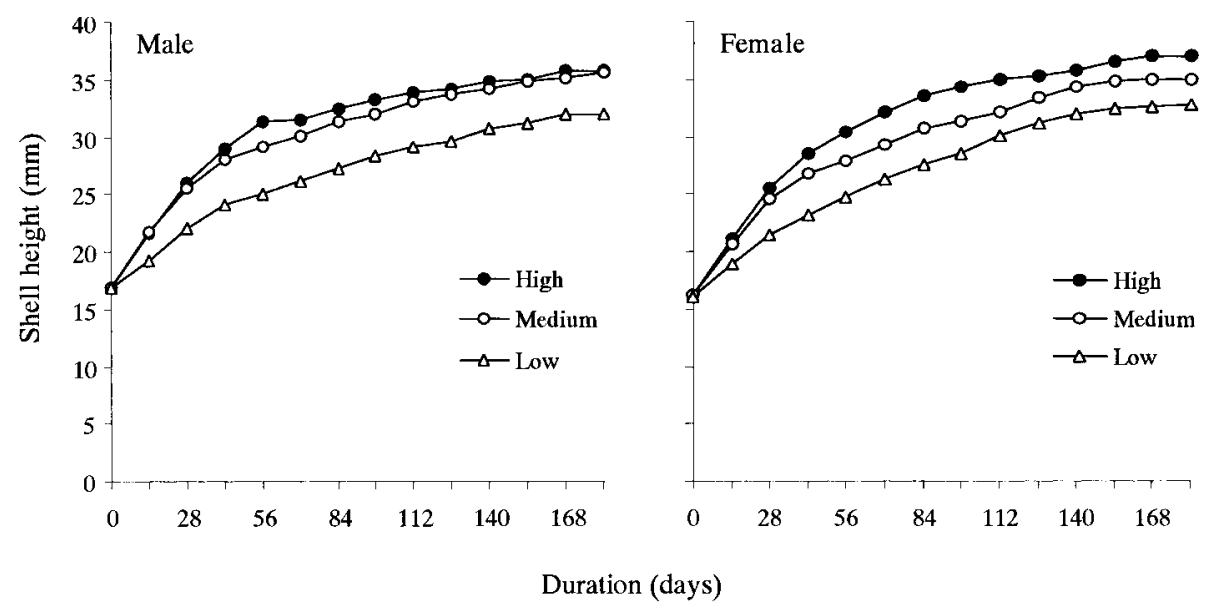

Fig. 1. Changes in mean shell heights $(\mathrm{mm})$ of P. canaliculata reared at low, medium and high food levels.

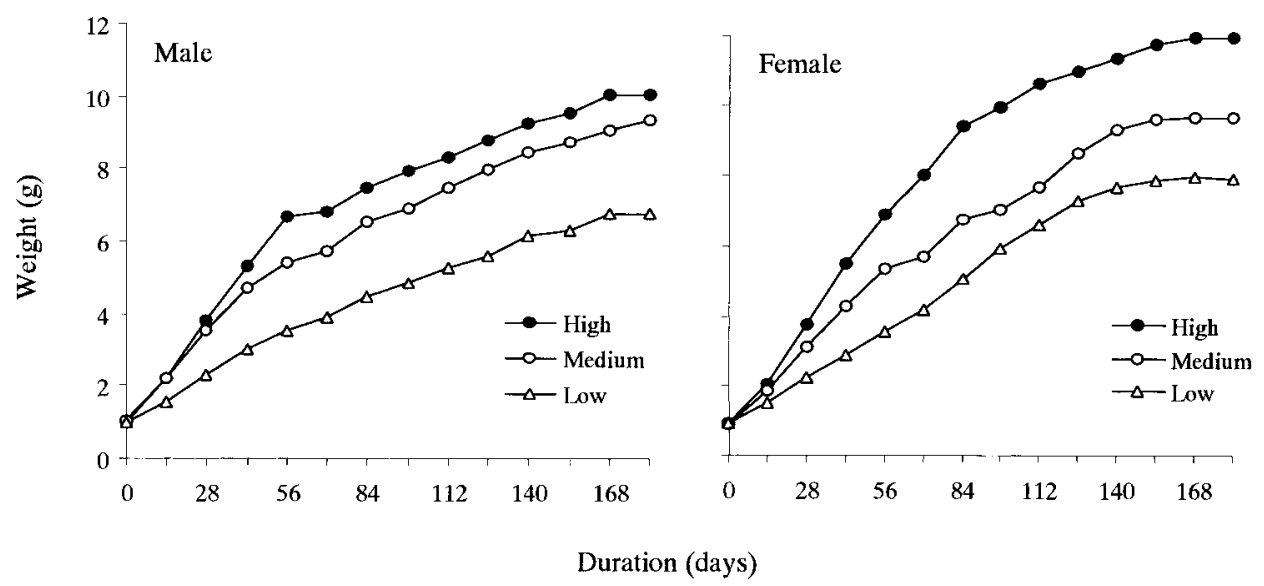

Fig. 2. Changes in mean weights ( $\mathrm{g}$ ) of P. canaliculata reared at low, medium and high food levels.

normally distributed. Multiple comparisons between two food levels were treated using MannWhitney $U$-test, setting the significant level at 0.0167 ( $=0.05 / 3$, Bonferroni's method; Yamamura, 1993). Statistical analyses were done using StatView (version 5.0.1) statistical software program (SAS Institute, 1998).

\section{RESULTS}

\section{Snail growth}

The food level had a marked effect on the growth of $P$. canaliculata. In males, significant differences in shell height and weight (Figs. 1 and 2) were observed starting from $14 \mathrm{~d}$ after treatment application (DAT) until the experiment was terminated on 182 DAT $(p<0.05$, ANOVA). Multiple comparisons between treatments revealed that the snails fed at low food level always had lower shell height and lighter weight than those fed at medium or high food levels after 14 DAT (Figs. 1 and 2; $p<0.05$, Tukey-Kramer test). Comparable shell height and weight were recorded for the snails in the medium and high food levels in all observations $(p>0.05$, Tukey-Kramer test) except on 56 DAT $(p<0.05)$.

In females, growth differences in shell height and weight (Figs. 1 and 2) commenced on 14 DAT and onwards ( $p<0.05$, ANOVA). In most observations, the snails fed at the low food level were lower in shell height and lighter in weight than those fed at medium or high food levels, and those fed at the medium food level were lower and lighter than those fed at the high food level $(p<0.05$, Tukey-Kramer test). The male and female growth curves tended to be similar up to 56 
DAT and thereafter females became larger than males at all food levels (Figs. 1 and 2).

The mortalities of the snails were low (2.5$7.5 \%$, depending on food levels) in males and slightly higher $(8.6-17.9 \%)$ in females. In both sexes, there was no difference in the proportion of dead or live snails at the different food levels $(p>$ 0.5 for males; $p>0.3$ for females, $G$-test).

\section{Size and age at first copulation-male snails}

Food level affected the shell height and weight at first copulation in male P. canaliculata (Table 1; $p<0.001$, ANOVA). Multiple comparisons between food levels indicated that the snails fed at low food levels copulated at lower shell height and lighter in weight $(p<0.05$, Tukey-Kramer test). However, the snails fed at medium and high food levels resulted in comparable shell heights and weights at first copulation $(p>0.05)$. In addition, the food level appeared to affect the penis sheath length, but the difference did not reach a statistically significant level $(p=0.06)$, probably due to a small number of snails dissected. Days to first copulation (relative age at maturity) were not different among snails at different food levels ( $p>0.3$, Kruskal-Wallis test).

\section{Size and age at first copulation-female snails}

Significant differences were recorded on the shell height and weight at first copulation in female snails (Table $2 ; p<0.001$, ANOVA). Multiple comparisons between food levels revealed that the snails fed at the low food level had lower shell height than those fed at the medium or high food levels ( $p<0.05$, Tukey-Kramer test). Weight at first copulation was different among all food levels $(p<0.05)$. Dissected snail samples revealed that the albumen gland weight was also significantly different (Table $2 ; p<0.05$, ANOVA). Days to first copulation were significantly different among snails fed at different food levels $(p<0.001$, Kruskal-Wallis test). Snails fed at the high food level copulated earlier than those fed at low or medium food levels $(p<0.0167$, Mann-Whitney $U$ test), but the difference between medium and low food levels did not reach a statistically significant level $(p=0.05)$.

At all food levels, females began to copulate 21$42 \mathrm{~d}$ (depending on food levels) later than males, with greater shell height and weight (Tables 1 and 2 ; all $p<0.001$, unpaired $t$-test).

Table 1. Size and age (d) of male P. canaliculata at first copulation

\begin{tabular}{|c|c|c|c|c|c|c|c|}
\hline Food level $^{\mathrm{a}}$ & $\begin{array}{c}\text { No. of } \\
\text { snails } \\
\text { available }^{\text {b }}\end{array}$ & $\begin{array}{c}\text { No. of } \\
\text { snails mated }\end{array}$ & $\begin{array}{l}\text { Shell height } \\
(\mathrm{mm})\end{array}$ & $\begin{array}{l}\text { Weight }^{\mathrm{c}} \\
(\mathrm{g})\end{array}$ & $\begin{array}{l}\text { Days to first } \\
\text { copulation }^{c}\end{array}$ & $\begin{array}{c}\text { No. of } \\
\text { snails } \\
\text { dissected }\end{array}$ & $\begin{array}{c}\text { Penis sheath } \\
\text { length }^{\mathrm{c}} \\
(\mathrm{mm})\end{array}$ \\
\hline Low & 38 & 38 & $25.2 \pm 3.3 \mathrm{a}$ & $3.56 \pm 1.42 \mathrm{a}$ & $70.4 \pm 29.8 \mathrm{a}$ & 8 & $9.5 \pm 1.7 \mathrm{a}$ \\
\hline Medium & 37 & 37 & $29.0 \pm 3.1 \mathrm{~b}$ & $5.28 \pm 1.73 b$ & $66.5 \pm 29.8 \mathrm{a}$ & 8 & $11.3 \pm 1.2 \mathrm{a}$ \\
\hline High & 39 & 39 & $28.9 \pm 2.9 \mathrm{~b}$ & $5.26 \pm 1.40 \mathrm{~b}$ & $64.2 \pm 21.0 \mathrm{a}$ & 9 & $11.4 \pm 2.1 \mathrm{a}$ \\
\hline
\end{tabular}

${ }^{a}$ See Materials and Methods for detail.

${ }^{\mathrm{b}}$ Dead snails were excluded.

${ }^{\mathrm{c}}$ Values (mean $\pm \mathrm{SD}$ ) followed by the same letter within a column are not significantly different.

Table 2. Size and age (d) of female $P$. canaliculata at first copulation

\begin{tabular}{lccccccc}
\hline Food level $^{\mathrm{a}}$ & $\begin{array}{c}\text { No. of } \\
\text { snails } \\
\text { available }^{\mathrm{b}}\end{array}$ & $\begin{array}{c}\text { No. of } \\
\text { snails mated }\end{array}$ & $\begin{array}{c}\text { Shell height } \\
(\mathrm{mm})\end{array}$ & $\begin{array}{c}\text { Weight } \\
(\mathrm{g})\end{array}$ & $\begin{array}{c}\text { Days to first } \\
\text { copulation }^{\mathrm{c}}\end{array}$ & $\begin{array}{c}\text { No. of } \\
\text { snails } \\
\text { dissected }\end{array}$ & $\begin{array}{c}\text { Albumen } \\
\text { gland weight }^{\mathrm{c}} \\
(\mathrm{g})\end{array}$ \\
\hline Low & 46 & 45 & $29.8 \pm 3.6 \mathrm{a}$ & $6.26 \pm 2.16 \mathrm{a}$ & $112.8 \pm 33.2 \mathrm{a}$ & 11 & $0.42 \pm 0.40 \mathrm{a}$ \\
Medium & 53 & 50 & $32.1 \pm 3.6 \mathrm{~b}$ & $7.55 \pm 2.42 \mathrm{~b}$ & $100.3 \pm 31.9 \mathrm{a}$ & 11 & $1.01 \pm 0.63 \mathrm{~b}$ \\
High & 51 & 46 & $33.4 \pm 3.6 \mathrm{~b}$ & $9.07 \pm 2.72 \mathrm{c}$ & $84.8 \pm 24.8 \mathrm{~b}$ & 10 & $1.00 \pm 0.10 \mathrm{~b}$
\end{tabular}

\footnotetext{
${ }^{a}$ See Materials and Methods for detail.

${ }^{\mathrm{b}}$ Dead snails and misjudged sex at the start of the experiment were excluded.

${ }^{c}$ Values (mean \pm SD) followed by the same letter within a column are not significantly different.
} 
Table 3. Size and age (d) of female $P$. canaliculata at first spawning

\begin{tabular}{|c|c|c|c|c|c|c|c|c|}
\hline \multirow{2}{*}{ Food level $^{\mathrm{a}}$} & \multirow{2}{*}{$\begin{array}{c}\text { No. of } \\
\text { snails } \\
\text { available }^{\mathrm{b}}\end{array}$} & \multirow{2}{*}{$\begin{array}{l}\text { No. of } \\
\text { snails } \\
\text { spawned }\end{array}$} & \multirow{2}{*}{$\begin{array}{l}\text { Shell } \\
\text { height }^{\mathrm{c}} \\
(\mathrm{mm})\end{array}$} & \multirow{2}{*}{$\begin{array}{c}\text { Weight }^{\mathrm{c}} \\
(\mathrm{g})\end{array}$} & \multicolumn{2}{|c|}{ Days to first spawing ${ }^{c}$} & \multirow{2}{*}{$\begin{array}{c}\text { No. of } \\
\text { snails } \\
\text { dissected }\end{array}$} & \multirow{2}{*}{$\begin{array}{c}\text { Albumen } \\
\text { gland weight } \\
\text { (g) }\end{array}$} \\
\hline & & & & & $\mathrm{All}^{\mathrm{d}}$ & $50 \%{ }^{\mathrm{e}}$ & & \\
\hline Low & 34 & 24 & $32.9 \pm 2.0 \mathrm{a}$ & $8.07 \pm 1.36 \mathrm{a}$ & $139.7 \pm 31.1 \mathrm{a}$ & $125.3 \pm 19.4 \mathrm{a}$ & 9 & $1.01 \pm 0.45 \mathrm{a}$ \\
\hline Medium & 39 & 31 & $33.5 \pm 3.0 \mathrm{a}$ & $8.49 \pm 2.41 \mathrm{a}$ & $118.6 \pm 30.9 b$ & $100.2 \pm 15.9 \mathrm{~b}$ & 9 & $0.90 \pm 0.15 \mathrm{a}$ \\
\hline High & 36 & 32 & $35.8 \pm 4.0 \mathrm{~b}$ & $11.21 \pm 3.28 \mathrm{~b}$ & $105.0 \pm 31.2 \mathrm{~b}$ & $84.5 \pm 16.4 \mathrm{c}$ & 10 & $1.32 \pm 0.45 \mathrm{a}$ \\
\hline
\end{tabular}

${ }^{a}$ See Materials and Methods for detail.

${ }^{\mathrm{b}}$ Dead snails, dissected snails after copulation and misjudged sex at the start of the experiment were excluded.

${ }^{\mathrm{c}}$ Values $($ mean $\pm \mathrm{SD})$ followed by the same letter within a column are not significantly different.

${ }^{\mathrm{d}}$ Based on the total number of spawning females.

${ }^{\mathrm{e}}$ Based on the first $50 \%$ of spawning females.

\section{Size and age at first spawning}

The food level affected shell height and weight at first spawning in females (Table $3 ; p<0.05$, ANOVA). Snails fed at the high food level started spawning at greater shell height and weight than the snails fed at low or medium food levels. The food level resulted in a significantly different number of days to the first spawning $(p<0.001$, Kruskal-Wallis test). Multiple comparisons between food levels using all the spawning females revealed that snails fed at the low food level spawned later than snails fed at medium or high food levels (Table $3 ; p<0.0167$, Mann-Whitney $U$ test). When days to first spawning were compared based on the first $50 \%$ spawning females, the durations were significantly different at all food levels $(p<0.0167)$. Dissected snail samples revealed that the albumen gland weight was not significantly different among the food levels (Table $3 ; p>0.05$, ANOVA).

In all food levels, it took ca. $20 \mathrm{~d}$ from the first copulation to the first spawning, resulting in greater shell height and weight at spawning (Tables 2 and 3; all $p<0.01$, unpaired $t$-test). Comparison of the albumen gland weight at first copulation and first spawning revealed a significant difference in snails fed at low or high food levels ( $p<0.05$, unpaired $t$-test). However, no difference was observed from snails fed at the medium food level $(p>0.6)$.

\section{DISCUSSION}

Growth was related to the food level in $P$. canaliculata. In comparing the three food levels, growth in both sexes was slower in snails fed at the low food level than at the medium or high food lev- els. Diet (plant species; Estebenet, 1995) and snail density (Tanaka et al., 1999) have been known to affect growth in $P$. canaliculata. Mendoza et al. (1999) reported that both food level and food quality affected growth in $P$. bridgesii. In the present study, snail growth tended to be similar between males and females before sexual maturity. However, growth was continuous in females while growth tended to be slower in males after sexual maturity. Similar results on the sexual difference in growth were obtained in laboratory (Estebenet and Cazzaniga, 1998) or field populations (Tanaka et al., 1999) of $P$. canaliculata.

As a consequence of affected growth, the snails had variable size (shell height and weight) and age at first copulation and spawning. Males that received more food grew faster than males that received less food. However, males began to copulate at almost the same age irrespective of food level. Consequently, males fed at the low food level matured at a smaller size. On the other hand, females that received more food grew faster than females that received less food. Well-fed females started both copulation and spawning earlier at larger body size than poorly-fed females.

This sexual difference can be attributed to a difference in the relationship between size and reproductive success in both sexes (Stearns and Koella, 1986). In P. canaliculta, small males can almost equally compete with big males in copulation (Estoy et al., unpublished data), suggesting that size is not a critical factor in male reproductive success. Thus, males mature at an earlier time when there is a chance to copulate, irrespective of body size. On the other hand, reproductive success (fecundity) is proportional to body size in females 
(Miyahara et al., 1986). Therefore, poorly-fed females probably increase lifetime reproductive success by delaying their maturity until they reach a large size and accumulate more resources to become more fecund.

The penis sheath length of the poorly-fed males tended to be shorter at first copulation than betterfed males. However, this difference did not reach a statistically significant level. This implies that there is no critical size of the penis sheath for copulation. On the other hand, the albumen gland weight of the poorly-fed females was lighter at first copulation than better-fed snails. However, the albumen gland weight was similar at first spawning at all food levels. This suggests that albumen gland weight is an important factor in spawning but not in copulation. Probably, there is a critical weight of the albumen gland for the commencement of spawning.

In females, the difference between the first copulation and spawning (maturity) was ca. $20 \mathrm{~d}$ at all food levels. The early initiation of copulation before full maturation in females is not an artifact of the isolated pairs in this study, since in the paddy fields about $45 \%$ of copulating females had albumen glands lighter than $0.4 \mathrm{~g}$ (Estoy et al., unpublished data), the average value for females fed at the low food level in this study. Although the adaptive significance of this early copulation for females is not straightforward, such copulation by pre-mature females may be related to a strategy for males to obtain a high reproductive success. Isolated females can store sperm for ca. one month, as indicated by continuous spawning of fertile eggs without a new mating (Miyahara et al., 1986). Furthermore, although sperm competition in this snail is not fully understood, a preliminary study revealed that a female mated with two males in succession fertilized part of her eggs with sperm from the first male for up to one month (Yusa, unpublished data). Thus, males mating with pre-mature females may have a good chance to fertilize eggs.

Tanaka et al. (1999) demonstrated that high density affected growth and reproduction of the snails in the paddy, presumably by reducing food availability for each individual. This means that paddy fields should be food limited for the snails so that their life history will be affected. In this study, low food level delays spawning, suggesting a shorter reproductive period under temperate or sub-tropical conditions, because the snails' life cycle is an- nual with a defined breeding period in warmer months. Under tropical conditions, rice is planted twice or three times a year; delayed spawning would indicate fewer generations of snails. Thus, food availability has an important effect on the population dynamics of snails by affecting the onset of spawning. Food availability also affects the number of offspring through the reproductive effort of the snails (Estoy et al., unpublished data). Moreover, food availability might even affect survival of offspring in the field. Low food availability delays snail spawning and accordingly sizes of offspring at wintering would be smaller. This is the case especially when low food availability reduces growth rates of offspring. Snails with shell heights less than $10 \mathrm{~mm}$ have lower over winter survival rates than snails with intermediate sizes (Kiyota and Okuhara, 1987; Ozawa and Makino, 1988). Thus, limited food availability might result in low survival of offspring by keeping their sizes small at wintering.

In the paddy fields, reducing food availability for snails can be done most practically by the removal of weeds (alternative food of the snail) along the levees. Weeding can also be effective in reducing food availability in irrigation and drainage canals, creeks and ponds. Another possible way to reduce food availability is keeping the water level shallower than the snail shell height, which reduces snail mobility (Ozawa et al., 1988; Ozawa and Makino, 1997). This technique is widely used after rice transplanting to avoid snail damage. However, if the same technique is applied for a longer period, the snails with limited feeding opportunity may have fewer offspring. These techniques should be most effective when combined with other existing methods of snail management (e.g. cultural, mechanical and chemical control; Kiyota and Sogawa, 1996; Wada, 1999; Suzuki et al., 2000).

\section{ACKNOWLEDGEMENTS}

We wish to thank Ms. Masayo Hashimoto and Mr. Kazuhiro Yoshida of the National Agricultural Research Center for Kyushu Okinawa Region for their assistance in the collection of the snails. The first author would also express his deep gratitude to the Ministry of Education, Science, Sports and Culture of Japan (Monbusho) for the scholarship grant.

\section{REFERENCES}

Albrecht, E. A., N. B. Carreno and A. Castro-Vazquez (1996) A quantitative study of copulation and spawning in the 
South American apple-snail, Pomacea canaliculata (Prosobranchia: Ampullariidae). Veliger 39: 142-147.

Cazzaniga, N. J. (1990) Sexual dimorphism in Pomacea canaliculata (Gastropoda: Ampullariidae). Veliger 33: 384-388.

Estebenet, A. L. (1995) Food and feeding in Pomacea canaliculata (Gastropoda: Ampullariidae). Veliger 38: 277-283.

Estebenet, A. L. and N. J. Cazzaniga (1992) Growth and demography of Pomacea canaliculata (Gastropoda: Ampullariidae) under laboratory conditions. Malacol. Rev. 25: $1-12$.

Estebenet, A. L. and N. J. Cazzaniga (1998) Sex-related differential growth in Pomacea canaliculata (Gastropoda: Ampullariidae). J. Moll. Stud. 64: 119-123.

Kaneshima, M., S. Yamauchi and K. Higa (1986) Sexual maturity of the apple snail, Ampullarius insularus. Proc. Assoc. Pl. Prot. Kyushu 32: 101-103 (in Japanese).

Kiyota, H. and K. Okuhara (1987) Overwintering ability of the apple snail, Pomacea canaliculata. Proc. Assoc. Pl. Prot. Kyushu 33: 102-105 (in Japanese).

Kiyota, H. and K. Sogawa (1996) Ecology and management of the apple snail in Kyushu, Japan. In Proceedings of the International Workshop on the Pest Management Strategies in Asian Monsoon Agroecosystems (N. Hokyo and G. Norton eds.). Kyushu National Agricultural Experiment Station, Kumamoto, pp. 187-195.

Mendoza, R., C. Aguilera, J. Montemayor and G. Rodriguez (1999) Utilization of artificial diets and effect of protein/energy relationship on growth performance of the apple snail Pomacea bridgesi (Prosobranchia: Ampullariidae). Veliger 42: 101-111.

Miyahara, Y., Y. Hirai and S. Oya (1986) Oviposition and hatching rate of Ampullarius insularus D'Obigny in Kyushu. Proc. Assoc. Pl. Prot. Kyushu 32: 96-100 (in Japanese with English summary).

Ozawa, A. and T. Makino (1988) Overwintering of the apple snail, Pomacea canaliculata (Lamarck) in Shizuoka Prefecture. Bull. Shizuoka Agric. Exp. Stn. 33: 65-77 (in Japanese with English summary).

Ozawa, A. and T. Makino (1997) The influence of shell size, snail density and water depth in paddy fields on injury of young rice seedling by the apple snails, Pomacea canaliculata (Lamarck). Bull. Shizuoka Agric. Exp. Stn. 42: 2329 (in Japanese with English summary).

Ozawa, A., T. Makino and S. Ozaki (1988) The relation between the depth of the water in a paddy field and injury to young rice seedlings by the apple snail, Pomacea canaliculata (Lamarck). Proc. Kanto-Tosan Pl. Prot. Soc. 35: 221-222 (in Japanese).

Roff, D. A. (1992) The Evolution of Life Histories: Theory and Analysis. Chapman and Hall, New York. 535 pp.

SAS Institute (1998) StatView for Windows Version 5.0.1. SAS Institute, Cary, North Carolina, USA.

Stearns, S. C. and J. C. Koella (1986) The evolution of phenotypic plasticity in life- history traits: predictions of reaction norms for age and size at maturity. Evolution 40: 893-913.

Suzuki, Y., M. Matsumura, K. Arimura, S. Urano, T. Wada, Y. Yusa and K. Ichinose (2000) Management of the apple snail, Pomacea canaliculata (Lamarck), by drainage and methaldehyde application in direct-sown rice under heavy rainfall conditions. Kyushu Pl. Prot. Res. 46: 94-97 (in Japanese with English summary).

Tanaka, K., T. Watanabe, H. Higuchi, K. Miyamoto, Y. Yusa, T. Kiyonaga, H. Kiyota, Y. Suzuki and T. Wada (1999) Density-dependent growth and reproduction of the apple snail, Pomacea canaliculata: a density manipulation experiment in a paddy field. Res. Popul. Ecol. 41: 253-262.

Thiengo, S. C. (1987) Observations on the morphology of Pomacea lineata (Spix, 1827) (Mollusca: Ampullariidae). Mem. Inst. Oswaldo Cruz, Rio de Janeiro 82: 563-570.

Wada, T. (1999) Introduction of the apple snail, Pomacea canaliculata and its impact on rice agriculture. In Proceedings of the International Workshop on Biological Invasions of Ecosystems by Pests and Beneficial Organisms (E. Yano, K. Matsuo, M. Shiyomi and D. A. Andow eds.). National Institute of Agro-Environmental Sciences, Tsukuba, pp. 143-151.

Yamamura, K. (1993) On the choice of multiple comparison procedures. Shokubutsu-boeki 47: 463-467 (in Japanese). 